\title{
EFFECT OF ROAD GRADE, VEHICLE SPEED AND VEHICLE TYPE ON NO 2 EMISSIONS ON URBAN ROADS IN JORDAN
}

\author{
JAWAD AL-RIFAI \\ School of Civil Engineering, Al-Ahliyya Amman University, Amman, Jordan \\ School of Civil Engineering, Philadelphia University, Jordan (formally)
}

\begin{abstract}
Motor vehicles emit gaseous air pollutants including sulphur dioxide, carbon monoxide $(\mathrm{CO})$, carbon dioxide $\left(\mathrm{CO}_{2}\right)$ nitrogen oxides $\left(\mathrm{NO}_{\mathrm{x}}\right)$, volatile organic compounds (VOC), and particulate matter (PM). Vehicle exhausts are confirmed as a main contributor to air pollution. The purpose of the study is intended to understanding emission rates of gases vehicle's emission in Jordan and to reveal the impact of driving conditions such as road grade, vehicle speed, number of vehicles and vehicle types in urban areas. In this study, gaseous emissions of $\mathrm{NO}_{2}$ were measured as an indicator for other vehicle gaseous pollutant. The maximum measured emission rate for $\mathrm{NO}_{2}$ was $0.15 \mathrm{ppm}$ and the mean average emission rate for $\mathrm{NO}_{2}$ was $0.077 \mathrm{ppm}$. Overall, our finding highlights a significant influence of road grade, speed, type and number of vehicle with the rate of $\mathrm{NO}_{2}$ emission. The observed trends indicate there is a need for further investigation to includes other gaseous pollutant.

Keywords: vehicle emission, $\mathrm{NO}_{2}$, traffic conditions, Jordan.
\end{abstract}

\section{INTRODUCTION}

Road transport is a major contributor to pollutant emissions in the Middle East and Northern Africa region (MENA). In the MENA region, vehicular transportation contribute to emission of $40 \%$ of $\mathrm{NO}_{\mathrm{x}}$ [1]. In California, motor vehicles were responsible for $51 \%$, of $\mathrm{NO}_{\mathrm{x}}$ [2]. In China, vehicle emissions accounted for 36\% [3]. Emissions originating from vehicle emissions have a significant impact on the atmosphere, health and the climate change [4]. Zheng et al. [3] demonstrated that vehicle emissions accounted for $67 \%, 36 \%, 39 \%, 36 \%$, and $22 \%$ of $\mathrm{CO}, \mathrm{NO}_{\mathrm{x}}, \mathrm{VOCs}, \mathrm{PM}_{2.5}$ and $\mathrm{PM}_{10}$, respectively, in the Pearl River Delta, China. Nitrogen oxides $\left(\mathrm{NO}_{\mathrm{x}}\right)$, comprising nitric oxide $(\mathrm{NO})$ and nitrogen dioxide $\left(\mathrm{NO}_{2}\right)$, are emitted during fossil fuel combustion processes. Associations between $\mathrm{NO}_{2}$ and adverse health effects, including mortality and morbidity, have been reported by many epidemiological studies [5], [6]. The vehicle number in Jordan has rapidly grown from 1.3 million to 1.35 million between 2014 and 2015, with around $75 \%$ of registered vehicle run on diesel (Fig. 1) [7].

In recent report, emissions of nitrogen oxides decreased by one third in the Twenty-Eight Member States of European United Countries, and 26\% in the Thirty-Three Member countries of European Environment Agency [8]. Unfortunately, there is a lake of research conducted in Jordan regarding on-road emission trends [9]. Al-Hasaan et al. [10] reported emission levels of $\mathrm{NO}_{2}$ at four monitoring sites in Amman during the period of July 1986 to June 1987.

Vehicle emissions were affected by operating modes, ambient conditions, driver behaviours, vehicle load and road grade [11]. Research studies have emphasised a significant influence road level on real-world fuel consumption and exhaust emission [12]-[14].

For test sections with positive road grade, as the gradient increases so must the engine power output to keep the vehicle at a constant speed, due to the increasing force of gravity 


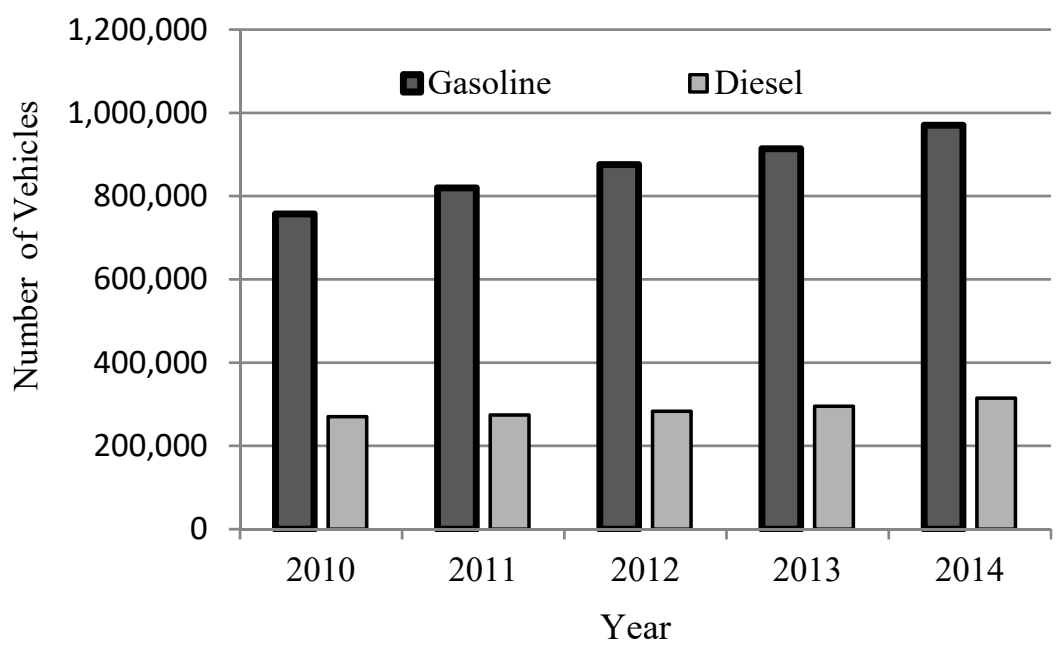

Figure 1: Number of Vehicles in Jordan between year 2010 and 2014.

opposing the motion of the vehicle. This increase in power requires greater fuel consumption resulting in increased $\mathrm{CO}_{2}$ exhaust emission. Likewise, where a vehicle is travelling on a road with negative grade, gravity acts to accelerate the vehicle, reducing the power demand on the engine, which lowers fuel consumption and hence $\mathrm{CO}_{2}$ emission. Zhang and Frey [14] recorded an increase in $\mathrm{CO}_{2}$ emission of $40-90 \%$ for three light duty gasoline vehicles over sections of road with gradient $5 \%$ when compared to sections with gradient $60 \%$, whilst Boriboonsomsin and Barth [12] measured a 15-20\% rise in fuel consumption for a gasoline passenger car between a flat route and a hilly route.

Ntziachristos and Samaras [16] showed that the correlation coefficients between average emission rates of $\mathrm{NO}_{\mathrm{x}}$ and speed were low $\left(\mathrm{r}^{2}: 0.34-0.56\right)$. de Vlieger [17] demonstrated that the emission rates of $\mathrm{NO}_{\mathrm{x}}$ and the consumption rates of fuel increased by $10 \%$, during rush hours compared with those of free flow conditions. The transport sector is the largest contributor to $\mathrm{NO}_{\mathrm{x}}$ emissions, accounting for $46 \%$ of total EU-28 emissions in 2012 but the introduction of catalytic converters reduced these emissions significantly [8].

This research aims to better understanding the effect of vehicle driving conditions on $\mathrm{NO}_{2}$ emission rates in urban area in Jordan.

\section{METHODOLOGY}

Jerash Road and King Abdullah bin Hussein II Road are frequently congested during rush hour and it compromises fixed road of $5.7 \mathrm{~km}$ route through the eastern entrance to Amman. The road was divided into different segments based on driving conditions such as traffic flow, vehicle's speed and road grade. The first segment has a slope of $6 \%$, the second segment has a slope of $4 \%$, the third segment has a slope of zero whereas, the last segment has a slope of $-2 \%$.

Nitrogen dioxide emissions were obtained using GrayWolf's AdvancedSense gaseous analysers. Traffic speed was measured with speed gun (Bushnell gun). Vehicle's type and speed were measured by manual count every 15 minutes during measuring emission rates at the measuring points. The vehicle's types were classified into gasoline and diesel vehicle [9]. 


\section{RESULTS AND DISCUSSION}

Emission rate for $\mathrm{NO}_{2}$ gas measured and the frequency is shown in Fig. 2. The maximum measured emission rate for $\mathrm{NO}_{2}$ during the rush hours was $0.15 \mathrm{ppm}$ and the mean average emission rates for $\mathrm{NO}_{2}$ was $0.08 \mathrm{ppm}$. The $\mathrm{NO}_{2}$ emission was below the maximum allowable concentration. The result was consistent with [10]. The reported emission rate at Downtown of Amman was between 0.01 to $0.08 \mathrm{ppm}$ for $\mathrm{NO}_{2}$. The motor vehicles were the major contributor to emission of $\mathrm{CO}$ and $\mathrm{NO}_{2}$ at the Downtown of Amman [10]. Deng et al. [18] reported high concentrations of $\mathrm{NO}_{\mathrm{x}}$ greater than $30 \mathrm{ppm}$ for vehicle fleet under real-world driving conditions of urban China.

There are significant correlations between road grade of $1 \%$ and $\mathrm{NO}_{2}$ emission (Table 1). Diesel vehicles and road grade have positive correlation with emission rates (Table 1). Fig. 3 shows the average $\mathrm{NO}_{2}$ emissions at various road levels $(-2 \%, 4 \%, 0 \%$ and $6 \%)$. The emission rates of $\mathrm{NO}_{2}$ at low level $(-2 \%)$ are lower than at higher level $(0 \%, 4 \%$ and $6 \%)$ At level of $-2 \%$, the average emission's for $\mathrm{NO}_{2}$ decreased by $100 \%$ (Fig. 3) while smaller decreases in emissions at other levels of roads compared to 6\%. Likewise, Deng et al. [18] reported that $\mathrm{NO}_{2}$ was released at higher rates on higher road level. The amount of fuel consumption and gaseous emissions is correlated to road level due to the resistance and traction of vehicles. As the road level increases and the gravity force increases, the vehicle's engine power must be increased to keep constant vehicle's speed.

This increase in power requires greater fuel consumption resulting in increased exhaust emission. Similarly, Zhang and Frey [14] recorded an increase in $\mathrm{CO}_{2}$ emission of 40-90\% for gasoline vehicles over sections of road with gradient $5 \%$ when compared to sections with gradient $60 \%$, and Boriboonsomsin and Barth [12] measured a $15-20 \%$ rise in fuel consumption for a gasoline passenger car between a flat route and a hilly route.

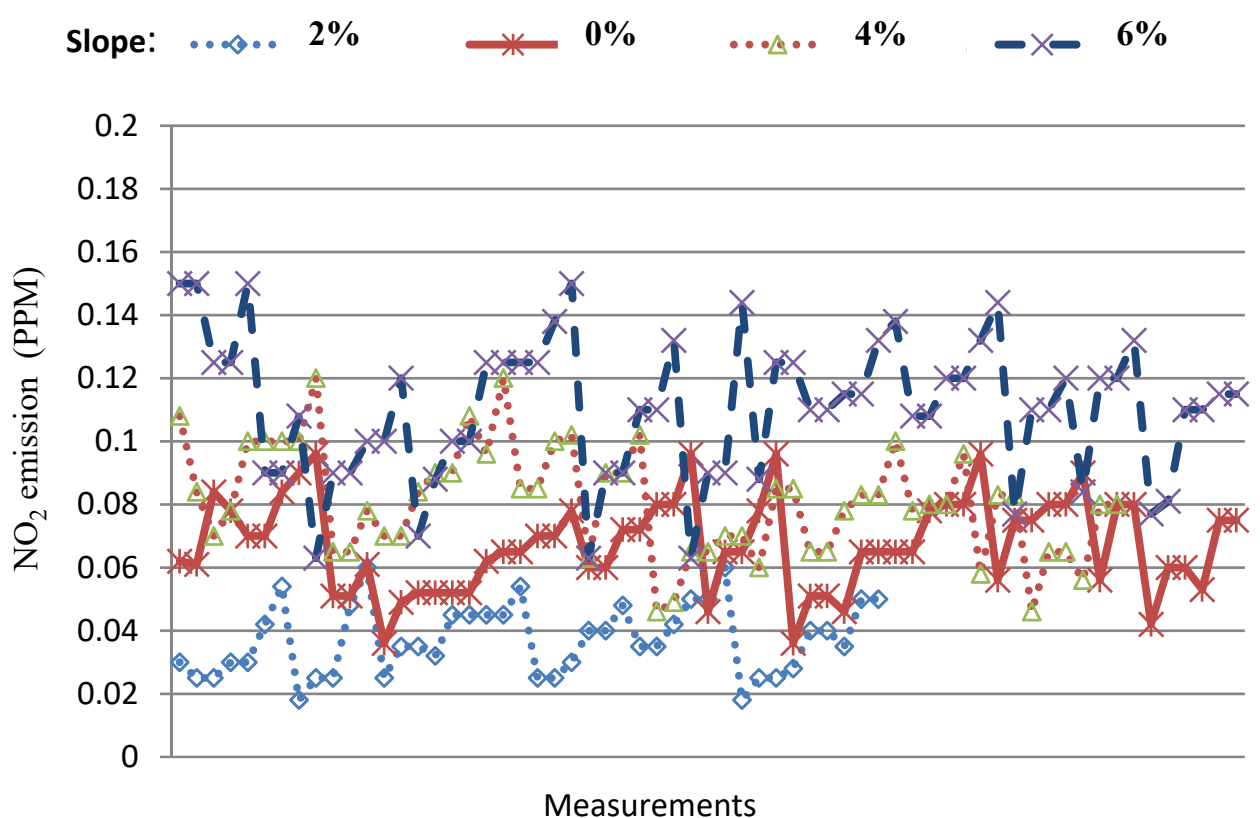

Figure 2: Frequency of measured vehicle's emission. 


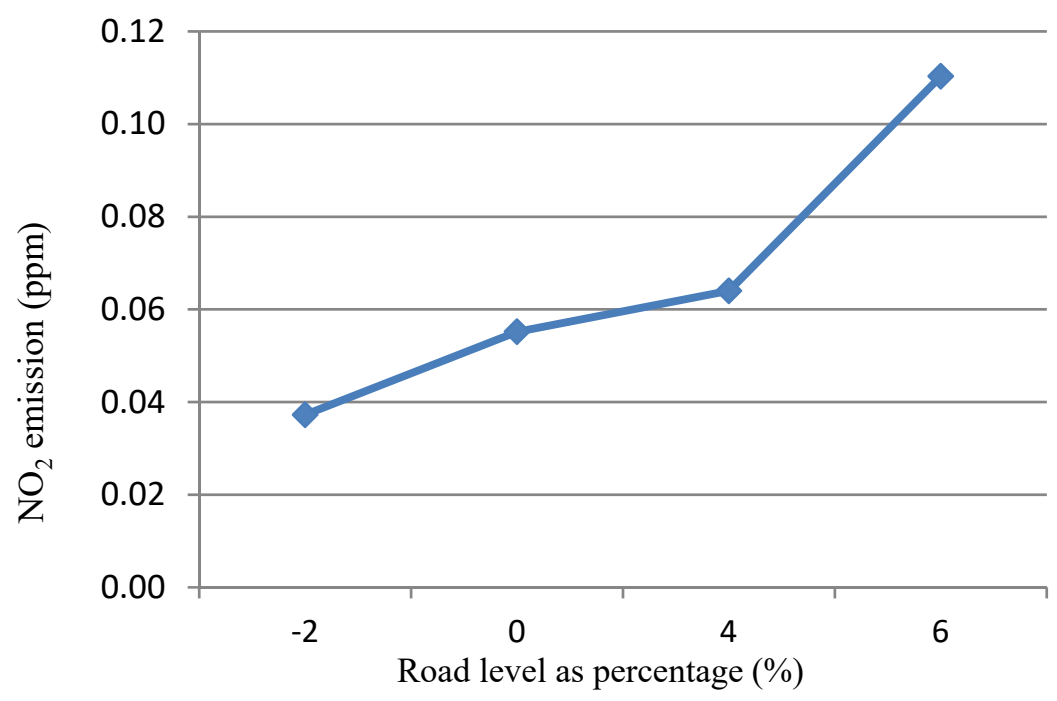

Figure 3: Average rate emission of $\mathrm{NO}_{2}$ at various road grades.

Table 1: Relationship between vehicle emission and road level, and vehicles type and speed.

\begin{tabular}{|c|c|c|c|c|c|c|}
\hline \multirow[b]{2}{*}{$\begin{array}{l}\text { Emission } \\
\text { gas (ppm) }\end{array}$} & \multirow[b]{2}{*}{ Average } & \multirow[b]{2}{*}{$\begin{array}{l}\text { Standard } \\
\text { Deviation }\end{array}$} & \multicolumn{4}{|c|}{ Correlation coefficient } \\
\hline & & & Road Level & $\begin{array}{l}\text { Gasoline } \\
\text { Vehicle }\end{array}$ & $\begin{array}{c}\text { Diesel } \\
\text { Vehicle }\end{array}$ & Speed \\
\hline $\mathrm{NO}_{2}$ & 0.08 & 0.03 & $0.8 * *$ & -0.7 & $0.4^{* *}$ & $0.4 * *$ \\
\hline
\end{tabular}

Fig. 4 Shows different rate of emissions at various speed segments. The emissions decrease significantly with increasing the vehicle's speed (Table 1). Driving at high speed reduces emission rates by $13 \%$ to $32 \%$ (Fig. 4 ), this could be as a result of reduction in fuel consumption with increasing speed. Ntziachristos and Samaras [16] showed that the correlation coefficients between average emission rates of $\mathrm{NO}_{\mathrm{x}}$ and speed were low $\left(\mathrm{r}^{2}: 0.34\right.$ 0.56). de Vlieger et al. [17] demonstrated that the emission rates of $\mathrm{NO}_{\mathrm{x}}$ and the consumption rates of fuel increased by $10 \%$, during rush hours compared with those of free flow conditions.

There are significant correlations between average emission rates and diesel vehicles (Table 1). Diesel vehicles have positive correlation with the average emission rates (Table 1), while gasoline vehicle has no significant effect increasing in emission rates of $\mathrm{NO}_{2}$.

\section{CONCLUSION}

The maximum measured emission rates for $\mathrm{NO}_{2}$ was $0.2 \mathrm{ppm}$. The emission was below the maximum allowable concentration according to the Jordanian Standards. There were significant correlations between average emission rates and road level, vehicle's speed and diesel vehicles. The emission rates increase with increasing the road level and driving at low speed, while gasoline vehicle had no significant influence on increasing $\mathrm{NO}_{2}$ emission compared to diesel vehicle. 


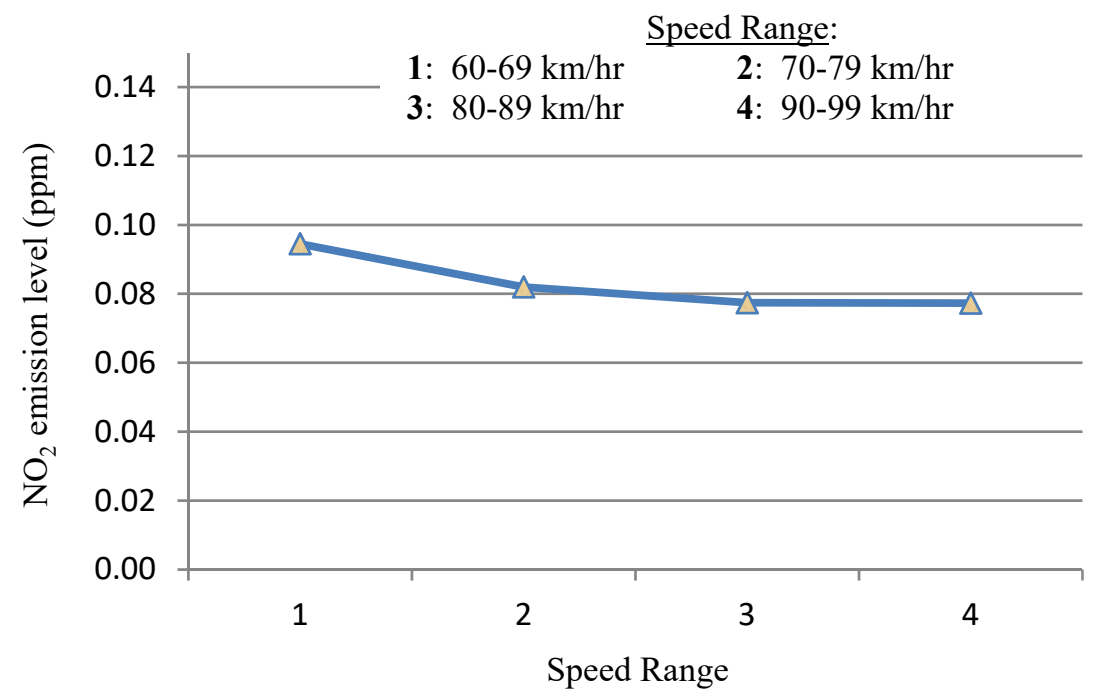

Figure 4: Average rate emissions of $\mathrm{NO}_{2}$ at vehicle speeds.

\section{ACKNOWLEDGEMENT}

The author would like to thank the support of the Philadelphia University for funding this research.

\section{REFERENCES}

[1] UNEP, Air Quality and Atmospheric Pollution in The Arab Region, Air Quality and Atmospheric Pollution in the Arab Region, UNEP, Editor. p. 40, 2015.

[2] Ban-Weiss, G.A. et al., Long-term changes in emissions of nitrogen oxides and particulate matter from on-road gasoline and diesel vehicles. Atmospheric Environment, 42(2), pp. 220-232, 2008.

[3] Zheng, J. et al., A highly resolved temporal and spatial air pollutant emission inventory for the Pearl River Delta region, China and its uncertainty assessment. Atmospheric Environment, 43(32), pp. 5112-5122, 2009.

[4] Waked, A. \& Afif, C., Emissions of air pollutants from road transport in Lebanon and other countries in the Middle East region. Atmospheric Environment, 61, pp. 446-452, 2012.

[5] Cesaroni, G. et al., Long-term exposure to urban air pollution and mortality in a cohort of more than a million adults in Rome. Environmental Health Perspectives, 121(3), pp. 324-331, 2013.

[6] Henschel, S. et al., Trends of nitrogen oxides in ambient air in nine European cities between 1999 and 2010. Atmospheric Environment, 117, pp. 234-241, 2015.

[7] Obeidat, O., Number of private cars estimated to rise to $1.35 \mathrm{~m}$ '. The Jordan Times 2015 [cited 2015 10/13/2015]; http://www.jordantimes.com/news/local/numberprivate-cars-estimated-rise- $135 \mathrm{~m} \% \mathrm{E} 2 \% 80 \% 99:[$.

[8] Guerreiro, C. et al., Air quality in Europe - 2014 Report. Luxembourg, 2014.

[9] Al-rifai, J., Corrolation analysis of driving conditions and on road emissions trends for vehicles. Journal of Urban and Environmental Engineering, 11(1), pp. 63-72, 2018. 
[10] Al-Hasaan, A.A., Dann, T.F. \& Brunet, P.F. Air pollution monitoring in Amman, Jordan. Journal of the Air \& Waste Management Association, 42(6), pp. 814-816, 1992.

[11] Ang, B.W. \& Fwa, T.F., A study on the fuel-consumption characteristics of public buses. Energy, 14(12), pp. 797-803, 1989.

[12] Boriboonsomsin, K. \& Barth, M., Impacts of road grade on fuel consumption and carbon dioxide emissions evidenced by use of advanced navigation systems. Transportation Research Record: Journal of the Transportation Research Board, 2139, pp. 21-30, 2009.

[13] Yazdani Boroujeni, B. \& Frey, H.C., Road grade quantification based on global positioning system data obtained from real-world vehicle fuel use and emissions measurements. Atmospheric Environment, 85(Supplement C), pp. 179-186, 2014.

[14] Zhang, K. \& Frey, C., Evaluation of response time of a portable system for in-use vehicle tailpipe emissions measurement. Environmental Science \& Technology, 42(1), pp. 221-227, 2008.

[15] Frey, H.C. et al., On-road measurement of vehicle tailpipe emissions using a portable instrument. Journal of the Air and Waste Management Association, 53(8), pp. 992$1002,2003$.

[16] Ntziachristos, L. \& Samaras, Z., Speed-dependent representative emission factors for catalyst passenger cars and influencing parameters. Atmospheric Environment, 34(27), pp. 4611-4619, 2000.

[17] de Vlieger, I., de Keukeleere, D. \& Kretzschmar, J.G., Environmental effects of driving behaviour and congestion related to passenger cars. Atmospheric Environment, 34(27), pp. 4649-4655, 2000.

[18] Deng, Y. et al., Measurements of real-world vehicle CO and NOx fleet average emissions in urban tunnels of two cities in China. Atmospheric Environment. 